\title{
IfISGUC.ORG
}

"iş, GÜÇ" ENDÜSTRi iLişKILERI VE INSAN KAYNAKLARI DERGISi

"IS, GUC" INDUSTRIAL RELATIONS AND HUMAN RESOURCES JOURNAL

\section{Elderly People Volunteering in Long-Term Care Facilities In Izmir, Turkey}

\author{
Sema OĞLAK \\ Department of Management, Faculty of Administration, Economics and Social Sciences \\ University of İstanbul Gelisim
}

\section{Shereen HUSSEIN}

Social Care Workforce Research Unit King's College London

Temmuz/July 2014, Cilt/Vol: 16, Sayı/Num: 3, Page: 94-105

ISSN: 1303-2860, DOI: 10.4026/1303-2860.2014.0257.x

Makalenin on-line kopyasına erişmek için / To reach the on-line copy of article: http://www.isguc.org/?p=article\&id=555\&cilt=16\&sayi $=3 \& y i l=2014$

Makale İçin İletişim/Correspondence to:

Sema OĞLAK, İstanbul Gelisim University, email:sema.oglak7@gmail.com 


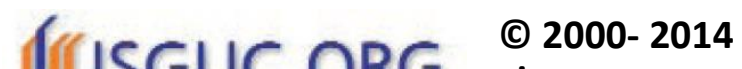 \\ "İ̧̧ü̈ç" Endüstri iliş̧kileri ve İnsan Kaynakları Dergisi \\ "Işsüç" Industrial Relations and Human Resources Journal
}

\author{
Temmuz/July 2014, Cilt/Vol: 16, Say1/Num: 3, Page: 94-105 \\ ISSN: 1303-2860, DOI: 10.4026/1303-2860.2014.0257.x
}

İs, Güç, Endüstri İlişkileri ve İnsan Kaynakları Dergisi, yılda dört kez yayınlanan hakemli, bilimsel elektronik dergidir.

Çalışma hayatına ilişkin makalelere yer verilen derginin temel amacı, belirlenen alanda akademik gelişime ve paylaşıma katkıda bulunmaktadır.

İs, Güç, Endüstri İlişkileri ve İnsan Kaynakları Dergisi, 'Türkçe' ve 'Ingilizce' olarak iki dilde makale yayinlanmaktadır.

Dergimiz İș, Güç; ulusal ve uluslararası birçok indekste taranmaktadır. (Cabells Directory, Ebsco Socindex, Index Islamicus, Index Copernicus, Worldwide Political Science Abstracts, Sociological Abstract, Ulakbim Sosyal BilimlerVeritani, Asos Index)

\section{Editörler Kurulu / Editorial Board} Aşkın Keser (Uludă̆ University) K.Ahmet Sevimli (Uludăg University) Şenol Baştürk (Uludağ University)

\section{Editör / Editor in Chief}

Şenol Baştürk (Uludăg University)

\section{Uygulama / Design}

Yusuf Budak (Kocaeli University)

Tarandĭ̆ı Indeksler/Indexes ASOS INDEX

CABELLS DIRECTORY EBSCO SOCINDEX

Index ISLAMICUS

Index COPERNICUS

Sociological Abstract

ULAKBİM Sosyal Bilimler

Veritanı

Worldwide Political Science

Abstracts

\author{
Yayın Kurulu / Editorial Board \\ Yrd.Doç.Dr.Zerrin Fırat (Uludă̆ University) \\ Prof.Dr.Aşkın Keser (Uludağ University) \\ Prof.Dr.Ahmet Selamoğlu (Kocaeli University) \\ Yrd.Doç.Dr.Ahmet Sevimli (Uludağ University) \\ Doç.Dr.Abdulkadir Şenkal (Kocaeli University) \\ Doç.Dr.Gözde Yılmaz (Marmara University) \\ Yrd.Doç.Dr.Dr.Memet Zencirkıran (Uludă̆ University)
}

Uluslararası Danışma Kurulu / International Advisory Board

Prof.Dr.Ronald Burke (York University-Kanada)

Assoc.Prof.Dr.Glenn Dawes (James Cook University-Avustralya)

Prof.Dr.Jan Dul (Erasmus University-Hollanda)

Prof.Dr.Alev Efendioğlu (University of San Francisco-ABD)

Prof.Dr.Adrian Furnham (University College London-Ingiltere)

Prof.Dr.Alan Geare (University of Otago- Yeni Zellanda)

Prof.Dr. Ricky Griffin (TAMU-Texas A\&M University-ABD)

Assoc. Prof. Dr. Diana Lipinskiene (Kaunos University-Litvanya)

Prof.Dr.George Manning (Northern Kentucky University-ABD)

Prof. Dr. William (L.) Murray (University of San Francisco-ABD)

Prof.Dr.Mustafa Özbilgin (Bruner University-UK)

Assoc. Prof. Owen Stanley (James Cook University-Avustralya)

Prof.Dr.Işık Urla Zeytinoğlu (McMaster University-Kanada)

$$
\begin{aligned}
& \text { Ulusal Danışma Kurulu / National Advisory Board } \\
& \text { Prof.Dr.Yusuf Alper (Uludă̆ University) } \\
& \text { Prof.Dr.Veysel Bozkurt (İstanbul University) } \\
& \text { Prof.Dr.Toker Dereli (Işık University) } \\
& \text { Prof.Dr.Nihat Erdoğmuş (İstanbul Şehir University) } \\
& \text { Prof.Dr.Ahmet Makal (Ankara University) } \\
& \text { Prof.Dr.Ahmet Selamoğlu (Kocaeli University) } \\
& \text { Prof.Dr.Nadir Suğur (Anadolu University) } \\
& \text { Prof.Dr.Nursel Telman (Maltepe University) } \\
& \text { Prof.Dr.Cavide Uyargil (İstanbul University) } \\
& \text { Prof.Dr.Engin Yıldırım (Anayasa Mahkemesi) } \\
& \text { Doç.Dr.Arzu Wasti (Sabancı University) }
\end{aligned}
$$

Dergide yayınlanan yazllardaki görüşler ve bu konudaki sorumluluk yazarlarına aittir.

Yayınlanan eserlerde yer alan tüm içerik kaynak gösterilmeden kullanılamaz.

All the opinions written in articles are under responsibilities of the outhors.

The published contents in the articles cannot be used without being cited 


\title{
Elderly People Volunteering in Long-Term Care Facilities In Izmir, Turkey
}

\author{
Sema OĞLAK \\ Department of Management, Faculty of Administration, Economics and Social Sciences \\ University of İstanbul Gelisim
}

Shereen HUSSEIN

Social Care Workforce Research Unit King's College London

$\ddot{O Z E T}$

Gönüllülük gibi sosyal yaşama katılım, sosyal hayatın içinde olma ve toplumsallaşma, yaşlıların yaşam kalitesi için çok önemli bir faaliyet olarak görülmektedir. Türkiye'de emeklilik sonrasında yaşlıların kamusal gönüllülükfaaliyetlerinde ne ölçüde yer aldı ğına ilişkin veriler oldukça yetersizdir. Gelişmiş ve gelişmekte olan toplumlarda nüfusun yaşlanmass ile birlikte uzun süreli bakım işgücüne talebin artacağının yanısıra sosyal katılım ve gönüllülük yoluyla bakım hizmeti verenlerin de yaşam kalitesinin yükseldiğine ilişkin kanıtlar giderek artmaktadır. Bu çalışma, İzmir'de kamuya ve özel kuruluşlara ait bakımevlerindeki gönüllü çalışmaların mevcudiyetini tesbit etmenin yanısıra 60 yaş üstündeki bireylerin bu kurumlarda gönüllülük faaliyetlerinde ne ölçüde yer aldıklarını belirlemeye yöneliktir. Çalışma bulguları, İmir'deki bakımevlerinde gönüllü çalışmaların yetersiz olduğu ve yaşlıların bakımevlerinde gönüllü olarak çalışmalara büyük oranda ilgi göstermediklerini göstermektedir.

Anahtar sözcükler: Toplumsal katılım, gönüllülük, uzun sureli bakım, Türkiye

\section{ABSTRACT}

Social inclusion and participation, including civic engagements such as volunteering, can be regarded as an important factor in quality of life of individuals particularly among older people. In the context of longer post retirement years in Turkey, there is a general lack of public activities available for older people. While the nature of contemporary demographic changes signal an increasing demand for lo ngterm care (LTC) workforce there is also emerging evidence that quality of life can be enhanced for caregivers through volunteering and social involvement. The current study reports on research aimed to determine within the city of Izmir in Turkey: 1) the extent of voluntary work in for profit as well as nonprofit residential LTC facilities, and 2) levels of participation of older people (60+) as volunteers in LTC facilities. The findings indicate that nearly 10 percent of Izmir LTC facilities benefits from older peoples voluntary work.

Keywords: Civic participation, volunteering, long-term care, Turkey 


\section{INTRODUCTION}

Volunteering is a cornerstone of civic engagement and a key element of social capital, which can be particularly important after retirement (Putnam, 2000). Volunteering in general is defined as taking responsibility for actions tow ards a person or community in an unpaid capacity, and spending time and effort without any profit (GHK, 2010:49; European Foundation for the Improvement of Living and Working Conditions [Eurofound], 2011). Formal volunteering is the voluntary activity carried out within an institutional structure for the benefit of others, while informal volunteering is the help and service that is performed for the benefit of family, friends or neighbors without the participation of any formal organization (Baines, Hardil \& Wilson, 2011). Formal volunteering is usually defined as 'highly active' civic engagement, in comparison to 'modest participation' such as contacting a local councilor or belonging to a social club. However, the concept of volunteering is extremely multifaceted and heterogeneous and there is no uniform definition.

Within the context of growing demand for long term careacross the world, volunteers can play an important, and otherwise unavailable, role in such services. Within a usually tight schedule of activities and over-loaded w orkforce, volunteers may be able to have the 'luxury of time' (Damianakis et al., 2007; Musson et al., 1997) with positive consequences on service users' moods and quality of life (Falkowski, 2013; Van der Ploeg et al., 2012). While volunteers within LTC contribute to both for-profit and non--profit organisations, they are significantly more present in the latter group (Falkowski, 2013; Hussein \& Manthorpe, 2012).

This article reports on a research project aimed at establishing the contribution of volunteers, particularly of relatively older age groups (60 years or older), in voluntary organizations providing different long-term care services in Izmir, Turkey. The article starts by discussing the values and challenges in old-age volunteering, then sets the context of volunteering in Turkey with a specific focus on long term care provision. We focus on the city of Izmir where the proportion of the population over the age of 65 is 9 percent, which is higher than the Turkey average of 7 percent (Türkiye İstatistik Kurumu-Turkish Statistical Institute [TUIK], 2010). Within Izmir, some districts such as Karaburun, Karşıyaka and Konak this percentage is between 15 and 19 percent (TUIK, 2010). Izmir is an important province in terms of the number of residential aged care homes: it contains approximately 15 percent of the total number of residential aged care homes from Turkey (Aile ve Sosyal Politikalar Bakanlığ1- Ministry of Family and Social Policies [MFSP], 2011).

\section{Voluntary Organisations and Volunteering in Turkey}

In Turkey, like in many other countries, voluntary organizations make significant contributions to the development of public social services, which is the state's basic responsibility (Özalp, 2008; Türkiye Üçüncü Sektör Vakfi- Turkey Third Sector Foundation [TÜSEV], 2011). They are perceived to strengthen social bonds, provide access to health and social care services and support individuals in need of care ([TÜSEV], 2006; Borell \& Gerdner, 2011). Historically, concepts of volunteering and civil society in Turkey has been revitalized as a result of several internal and external factors, especially in the post-1980 era, and has gained prominence in academic, social and political discourse (Icduygu, Meydanoglu \& Sert. 2011). The development of the voluntary sector gained particular momentum following the aftermath of the Cold War and within the context of heavy globalization (Icduygu et al., 2011). A number of developments that were inherited from the late 1990s shaped the dynamics of civil society in the millennium. The first such milestone came in the form of the 1999 Marmara earthquakes. These disasters mobilized voluntary groups and non-governmental organizations and increased society's interest and trust in civil society as citizens participated through volunteering and 
donations. And these played significant roles in the transformation of civil society in Turkey (Yeğen, Keyman, Çalışkan \& Tol, 2010; Icduygu, Meydanoglu, Sert, 2011), with around 65 percent of all voluntary organizations in Turkey focuse on social services' activities (Icduygu et al., 2011).

However, the concept of active and formal volunteering appears to be under-developed in Turkey for several reasons. Firstly, formal volunteering is not widely accepted in the structure of social perception and thinking within the Turkish society (Özel Sektör Gönüllüler Derneği- Corporate Volunteer Association [OSGD], 2006). Secondly, public opinion of mistrusting the purpose of volunteering is evident in Turkey and may relate to a wider lack of confidence in nongovernmental organizations (TÜSEV, 2006: 119; Pires, Prouteau \& Sardinha, 2010). Some groups are perceived to be (mis)using charitable institutions to carry out their political and ideological agendas and this may give rise to suspicious attitudes to voluntary organizations in general and may negatively affect the development of volunteering (TÜSEV, 2006). Other possible reasons for the low uptake of formal volunteering in Turkey may relate to the reduction and/or delay of transfer of appropriate resources between organizations and their effective use due to bureaucratic obstacles and financial problems (Yildirim \& Yildirim, 2011). These individual and structural barriers are topped up with some inadequacies of the national policy and regulations in relation to service provision at state and local levels in Turkey (Araştırma ve Etütler Merkezi [AREM], 2008, Devlet Planlama Teşkilatı- Turkish State Planning Organisation [DPT], 2007). On the individual level, lack of time and low perception of associated rewards have been shown to be significant barriers to volunteering (Yildirim \& Yildirim, 2011).

\section{Volunteering After Retirement}

With increased life expectancy across the globe, many countries have adopted some form of aging policies, some are more established and well developed than others, but most place emphasis on the overall wellbeing and independence of older people (OECD, 2011). As part of such independence and active aging, volunteering after retirement can be viewed as a winning strategy to enhance people lives and maximize their contribution to the society. For example, in the United States of America (USA) and the United Kingdom (UK), the contribution of volunteers in providing long-term care is gaining increasing attention (Falkow ski, 2013; Hussein \& Manthorpe, 2012). Early religious and philanthropic efforts led to a flourishing voluntary sector in many developed and developing countries focused in the majority in providing welfare services (GHK, 2010). At the same time, the voluntary sector, which attracts most volunteers, has long been an important provider of care services in many countries (Knapp, Koutsogeorgopoulou \& Smith, 1996). In most economically developed countries, the majority of volunteers offer their services to non-profit or voluntary organisations, mostly undertaking human services work (Wilson et al. 2005; Butler \& Eckart 2007).

In recent years, research on the social dimensions of health such as social integration, social network and support have been gaining great momentum due to the associated demands of aging and long-term care needs. There is also increasing recognition of health and social value of regular engagement in socially meaningful activities, especially for older people. Studies have shown that volunteering for some older people represents important means for undertaking productive activity in older age with consequent benefits that include enhanced quality of life, reduction in stress and depression levels and improved self-confidence (Lum \& Lightfoot, 2005; Dykstra, 2009; Stanley et al, 2010).

Loneliness and exclusion from mainstream community life are frequent social problems in old age in many countries including Turkey (Tilvis et al, 2011; Stanley et al, 2010; Dykstra, 2009) with strong relationship between loneliness and entry to a nursing home or residential aged care facility in later life. Voluntary work can be an effective tool 
contributing to the social inclusion of older people and may in some circumstances prevent or delay their need for future older people residential care (Bluth, 2010; Eurofound, 2010;Tang, Morrow-Howell \& Hong, 2009). Thus, older-age volunteering in service sectors such as long-term aged care offers a 'virtuous circle' of benefits (Pennix, 2006; Hussein \& Manthorpe, 2012).

Due to cultural and historical differences, formal volunteering (of all age groups) varies across the countries of the European Union (EU). The "European Social Reality" survey (Eurobarometer (2007) shows that Austria, the Netherlands and Sweden are the countries where people volunteer the most; with 60, 55 and 53 per cent of people aged 16 or more volunteering respectively (GHK, 2010; Pires, Prouteau \& Sardinha, 2010). The survey from Eurofound (2011) showed that in the EU, especially in the UK, Belgium, Denmark, Germany and Spain, participation of the elderly in volunteering is increasing and approximately 3 out of 10 adults are engaged in some type of organized voluntary work. In the USA older people have been more engaged in voluntary work in recent years than in the past, especially in the area of social services (Gottlieb \& Gillespie, 2008; Tang et al., 2009).

In Turkey, according to YADA survey (2012), the majority of voluntary organizations' members are men, with 16.4 percent over the age of 50 (Yeğen, Keyman, Çalışkan, Tol, 2010). Overall volunteering activities in Turkey are considerably low, with only $2.5 \%$ and $4.2 \%$ provide volunteer support to social or political organisations. Donations to NGOs are also low in Turkey: according to an international study, only $14 \%$ of the public have made a financial donation to a NGO within the last month. The same study places Turkey $134^{\text {th }}$ out of 153 in terms of donations, volunteerism and helping a stranger. According to the Icduygu, Meydanoglu, Sert (2011) study from various regions of Turkey "the number of youth under 25 years, elderly individuals 65 and over and women who are involved in voluntary organizations is almost zero or far less than required".

\section{Aims of the Study}

In the scope of the "European Year of Volunteering" (2011), the focus of this study is on the city of Izmir with the objectives to 1) determine contribution of volunteers in forprofit and not-for-profit residential aged care homes in Izmir, Turkey and 2) investigate the extent of participation of elderly people in residential aged care homes as volunteers. In particular, the research study attempted to address the following two questions:

1. Is there an organizational structure or support framework for encouraging volunteer work in residential aged care homes operating in Izmir?

2. What percentage of volunteering in residential aged care homes is undertaken by people 60 and over?

\section{Context and Methods:}

Izmir is a port city situated in western Turkey on the gulf of Izmir, with a population of nearly four million. It is a center of trade and tourism and is Turkey's third largest city in terms of economic development. Mostly due to favorable climate and high quality of life it is one of the places strongly preferred by elderly and retired people.

This study is a descriptive and cross-sectional field study and covers state, municipal, foundation as well as private residential aged care homes operating within the borders of the Izmir Province and aims to determine the extent of volunteers and voluntary work in those institutions. There are a total of 41 residential care homes in Izmir that are either run by state, municipal, foundation or forprofit organizations, the focus of this research is on these 41 residential care homes. This study was conducted under the leadership of Narlidere District Governorship between the $14^{\text {th }}$ of April and 30th of May of 2011. Data were collected by contacting all residential care homes and through written and telephone interviews. Interviews with operational managers of these institutions collected information on the presence and numbers of volunteers, detailed information on their 
profile, years of service and their roles in the organization. All residential care homes in Izmir responded to either a postal or phone questionnaire, thus the study had a response rate of $100 \%$.

\section{FINDINGS}

Table 1 provides the distribution of participating residential aged care, 68 percent are voluntary not-for-profit organization, 15 percent are state owned, 10 percent foundation and 3 percent belong to municipalities. While only 15 percent of residential aged care homes are owned by the state, a total of 54 percent of total number of beds are funded by the state. However, for profit-organizations own only one fifth of the share in terms of the bed capacity.

\section{Table 1: Distribution of the number of residential care homes and volunteers} based on the institutions (2011)

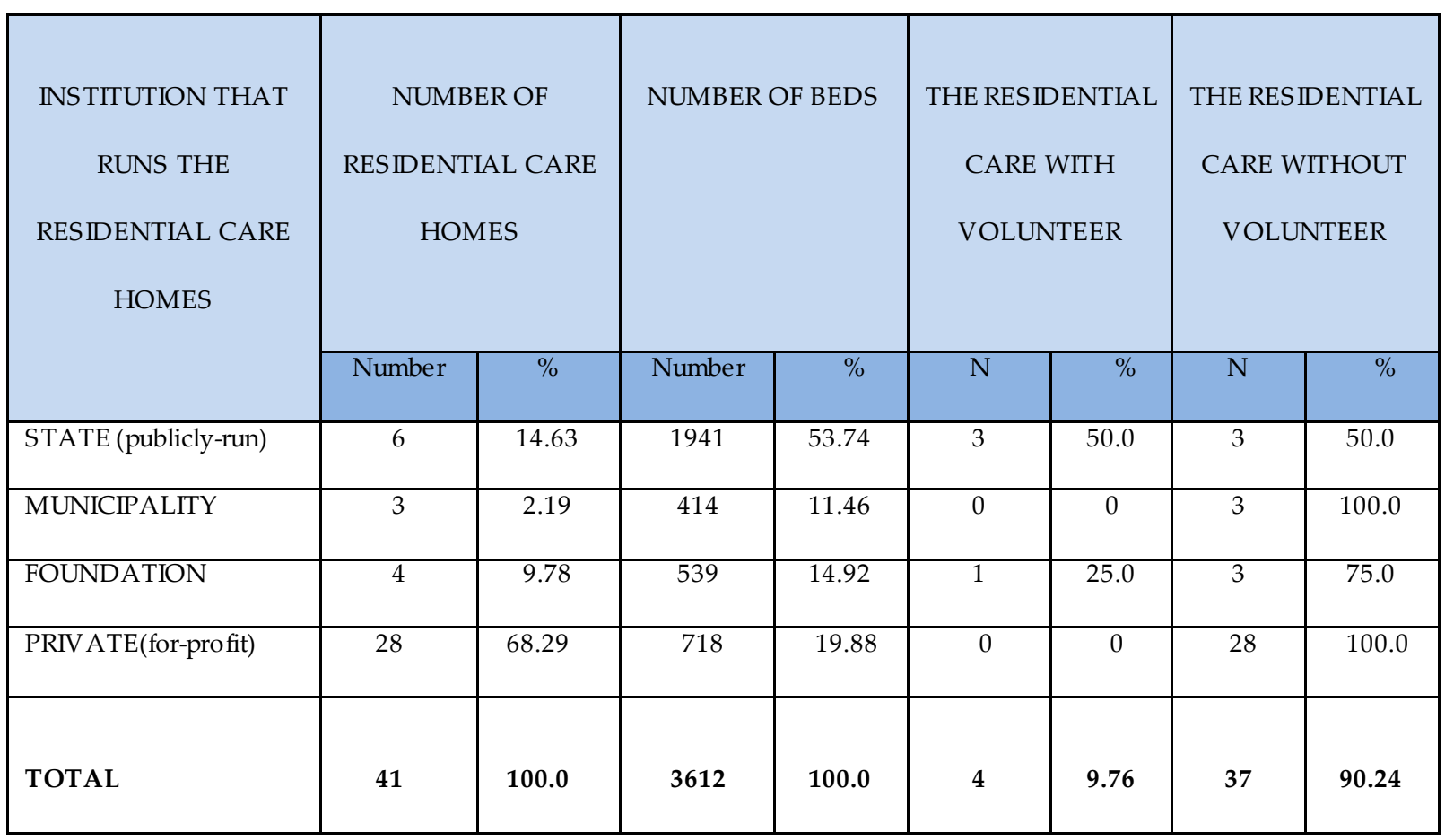

Table 1 indicates that 37 residential aged care homes $(90 \%)$ did not report having any volunteer workers. None of the for-profit and municipal residential aged care homes reported any volunteer workers. Among four residential aged care homes $(10 \%)$ that had volunteers, three were state owned while one belonged to a foundation residential aged care facility. Low number of volunteers may reflect the reality of the contribution of volunteers or may be due to not reporting of some volunteers, especially those who contribute in an irregular pattern or due to the nature of volunteers' contribution. However, the low reported contribution of volunteers in formal long-term care settings is consistent with other research from the United Kingdom (Hussein, 2011).

Table 2 lists the number of workers in the residential aged carehomes that had voluntary work. The total number of volunteers in those institutions was 75. Only one residential aged care home had volunteer workers for seventeen years, one had a volunteer program for five years and the other two residential aged care homes have been having volunteers for only one year. 

Table 2: Number of volunteer workers in residential care homes that allow voluntary work and time since allowing the volunteer work

\begin{tabular}{|l|l|l|}
\hline \multicolumn{1}{|c|}{ RESIDENTIAL CARE HOMES } & Number of & Work Time (Years) \\
WITH VOLUNTEER & Volunteers & \\
\hline STATE & 50 & 1 \\
\hline STATE & 11 & 17 \\
\hline STATE & 8 & 1 \\
\hline FOUNDATION & 6 & 5 \\
\hline TOTAL & 75 & \\
\hline
\end{tabular}

Table 3 shows that the age group of 18-29 year olds has the highest rate of participation in voluntary work with $68 \%$. The age group of $46-60$ years had $18.67 \%$ of participants, while for the age group of above 61 years this was only $5.53 \%$. Volunteers were engaged in activities such as choir, music, painting, artistic activities, reading, chatting, and sports rather than the services related to activities of daily living (ADLs).

Table 3: Age Distribution of Volunteers

\begin{tabular}{|l|l|l|}
\hline Age & Number & $\%$ \\
\hline $18-29$ & 51 & 68.0 \\
\hline $30-44$ & 6 & 8.0 \\
\hline $45-60$ & 14 & 18.67 \\
\hline 61 and + & 4 & 5.33 \\
\hline TOTAL & 75 & $\mathbf{1 0 0 . 0}$ \\
\hline
\end{tabular}




\section{Discussion}

This study aimed to determine the extent and status of voluntary work and participation of elderly people in voluntary work in Izmir residential aged care homes owned by the state, municipalities, foundations and private owned organizations. The results obtained by this study indicate that volunteering is not an integral component of the infrastructure in residential aged carehomes operating in Izmir. In the residential aged care homes where voluntary w ork takes place, those activities are entirely at the initiative of the institution and are limited solely to cultural activities. However, they are integral component of the infrastructure. Apart from several sincere voluntary workers in some residential aged care homes, it can be said there are almost no attempts in the area of volunteering and that a lot of ground still needs to be covered. However, such initiatives as letting the volunteer old people benefit from tax reduction, allowing priority for participation in some entertainment and social activities and tax deductions, introduction of incentive systems in transportation should be materialized.

In particular, lack of volunteers and any voluntary work in private owned residential aged care homes could be seen as indications of insufficient public awareness and participation despite the presence of legislation to boost volunteering. Social education, from as young as primary and secondary schooling, should be designed so as to relate the benefits of participating in volunteering activities for one-self in later ages and thus increase the aw areness of positive rew ards associated with volunteering activities. On the other hand, it will be very beneficial if the infrastructure of social care institutions is reviewed in terms of extending volunteering and maintaining its sustainability introducing reward/incentive practices within the scope of existing arrangements.

The fact that older people, however small in number, are contributing their time and efforts in residential aged care homes on a volunteer basis indicates the potential of developing a systematic way of encouraging and facilitating voluntary initiatives with the long term care sector. The findings indicate that the uptake of volunteering activities by older groups is relatively low, such age group differences are similar to studies (Yildirim \& Yildirim, 2011; TEGV, 2008; Palaz \& Boz, 2008; Icduygu, Meydanoglu \& Sert, 2011). There are limited studies and programs related to young people's voluntary work for elderly care to examine the extent of these age-group differences. However, previous research in Turkey by Hablemitoğlu and colleagues (2011:159) stated that 'young people's voluntary services for the elderly have great importance for people in elderly care centres with major spiritual value to these services'.

While the majority of existing volunteers might be individuals from young age groups, individuals 60 years of age and over in this study have shown some interest in voluntary works in domains where they can relate to the service provided and those receiving such services as the case in long term care settings. Higher volunteering participation rates of younger age groups could be explained on economic reasons, volunteering can be viewed as means to enter the labor market. How ever, one could also argue that this is due to the fact that such a practice, of volunteering at old age, is not a well-grounded tradition in contemporary Turkish culture. Izmir's elderly population is above Turkey`s average and the number of residential aged care homes is more than any other city in the country. The result of our study is important in two ways: first, despite the presence of legislation to encourage and to develop volunteering, 90 percent of the residential aged care homes lack infrastructural support for attracting and holding volunteer workers. Secondly, in the residential aged care homes that have opportunities for voluntary w ork, older retired people are not actively participating in existing activity programs.

In addition, the result of this study showed the need for further research on internal and external factors relevant for attracting more volunteers for elderly care, particularly among 
older retired persons. It is perhaps important to understand that older volunteers have the potential to play a crucial role in the overall care of older people living in residential aged care facilities throughout Turkey. Effective inclusion of older volunteers will require appropriate training, support and supervision in order to ensure that the service they provide is valued by residents, staff and family members. Equally important is the need for older volunteers to feel that their respective roles are valued and fit within the overall framework of quality care. In this way, volunteerism placed in an appropriate structural framework can be an effective means for utilizing the talents and skills of older retired people as well as providing an effective means for combating loneliness and social exclusion. Both the state and NGOs have a great responsibility to prepare legal infrastructure appropriate for Turkey's sociocultural structure and to carry out systematic studies directed to increase the social aw areness of the value related to engagement in formal volunteer work. Their responsibility also includes encouraging older people to volunteer in social care institutions, through structured incentives and/or promoting the value of such activities. In this respect, supporting voluntary organizations that provide participation of the elderly in the community offering an opportunity to fulfill their potential will benefit retirees and healthy elderly people along with contributing to the resolution of regional and national challenges.

\section{CONCLUSION}

This study provides a broad perspective on the presence of voluntary work in Izmir residential aged care homes and the extent of participation of elderly people in those residential settings. These results represent a preliminary excursion in older person volunteer work and are not sufficient to interpret the nationwide status of formal voluntary work by older people. Given the current situation, of aging population and associated needs, more comprehensive and large-scale research is needed to assess the participation of elderly people in volunteering.

In EU member countries the volunteer projects especially designed for social care services for elderly people greatly contributed to improving the quality of life and social participation of elderly people. In this context, "European Year of Volunteering 2011" and "European Year for Active Ageing and Solidarity between Generations, 2012" are great opportunities to develop incentive systems that provide support for voluntary organizations and volunteers in Izmir. Moreover, there are major potential to strengthen the social participation of elderly people, to promote a healthy and active aging population, and to encourage the adoption of a lifelong learning concept, where the more developed countries' solutions for good practice can be used as a guideline. 


\section{References:}

Araştırma ve Etütler Merkezi [AREM] (2008). “Yerel Yönetimlerde Gönüllü Katılım”. Kadın Hakları ve YerelYönetimler, “Kadın Dostu Kentlere Doğru". T.C. Içişleri Bakanlığ 1 Araştırma ve Etütler Merkezi(AREM). Yalçın Matbaacılık. Ankara.

Baines, S., Hardil, I. \& Wilson, R. (2011). Introduction: Remixing the Economy of Welfare? Changing Roles and Relationships between the State and the Voluntary and Community Sector. Social Policy $\mathcal{E}$ Society 10(3): 337-339.

Bluth, S. (2010). Policy Brief on Tapping the potential of Volunteering. United Nations Economic Commission For Europe. Workig Group on Ageing. Third meeting of the Working Group, Geneva (Switzerland), 22-23 November 2010. Population Unit. www.unece.org/pau (accessed 17/1/20133)

Borell, K. \& Gerdner, A. (2011). Hidden Voluntary SocialWork: A Nationally Representative Survey of Muslim Congre gations in Swe den, Brit ish Journal of Social Work. 41 (5): 968-979.

Boz, I. \& Palaz, S. (2007). Factors Influencing the Motivation of Turkey's Community Volunteers. Nonprofit and Voluntary Sector Quarterly. 36(4): 643-661.

Brewis, G, Russell, J. \& Holdsworth, C. (2010). Bursting the Bubble: Students, Volunteering and the Community. London: Institute for Volunteering Research.

Butler, S. \& Eckart, D. (2007). Civic engagement among older adults in a rural community. Journal of Community Practice, 15(3): 77-98.

Davis, S.J. \& Gay, P. (2005). Active Ageing in Active Communities Volunteering and the Transition to Retirement, Institute for Volunteering Research, Joseph Rowntree Foundation. Publishing: The Policy Press.

Dinckol, A. (2006). “Kopenhag Kriterlerinin Türk Pozitif Hukuku'na Etkileri", İstanbul Ticaret Üniversitesi Sosyal Bilimler Dergisi. 5, (10):25-48.

DPT, Devlet Planlama Teşkilatı(2007). Türkiye'de Yaşllarn Durumu ve Yaşlanma Ulusal Eylem Planı, Devlet Planlama TeşkilatıSosyal Sektörler ve Koordinasyon Genel Müdürlüğü, Yayın No: 2741

Dykstra, P.A. (2009). Older a dult loneliness: myths and realities, European Journal of Ageing , 6(2): 91-100.
Europe an Commission (2007). European Social Reality Report 2007, Special Eurobarometer 273.February, Europe an Social Reality. Special Euroba rometer 273 http://ec.europa.eu/public opinion/archives/ ebs/ebs 273 en.pdf (accessed 17/9/13).

European Foundation for the Improvement of Living and Working Conditions (Eurofound). (2010). Measures for social inclusion of the elderly: The case of volunteering. Working pa per. European Founda tion for the Improvement of Living and Working Conditions. www.eurofound.europa.eu (accessed 17/9/13).

European Foundation for the Improvement of Living and Working Conditions (Eurofound). (2011). Volunteering-a force for change.

http://www.eurofound.europa.eu/resourcepa cks/volunteering.htm (accessed 17/9/13).

GHK (2010). Study on Volunteering in the European Union Final Report. Educational, Audiovisual \& Culture Executive Agency (EAC-EA), Directora te General Education and Culture (DG EAC), http://ec.europa.eu/citizenship/pdf/doc1018 en.pdf (accessed 17/9/13).

Gottlieb, B.H. \& Gillespie, A.A. (2008).

Voluntee rism, health, and civic engagement a mong older a dults. Canadian Journal of Aging , 27(4):399-406.

Hablemitoğlu, S, Ozmete, E, Bayoğlu, A.S. \& Yıldırım, F. (2011). Evde Yaşlı Bakımı Hizmetlerinde Gönüllü Olmanın Gençlerin Yaşa mlarına Katkısı. C.Ü. İktisadive İdari Bilimler Dergisi, 12 (1), 147-163.

Hussein, S. \& Manthorpe, J. (2012). Volunteers supporting older people in formalcare settings in England: personal and local factors influencing prevalence and type of participation. Journal of Applied Gerontology. OnlineFirst 22nd August 2012, doi:10.1177/0733464812455098.

Hussein, S. (2011). Volunteers in the formallongterm care workforce. Social Care Workforce Periodical, Issue 13: June 2011, London: ISSN 2047-9638

http://www.kcl.ac.uk/scwru/pubs/periodical/ issues/scwp13.pdf (accessed 20/6/13).

Icduygu A, Meydanoglu Z \& Sert D.Ş. (2011). Civil Society in Turkey: At a Turning Point. CIVICUS Civil Society Index Project Analytical Country Report for Turkey II. 
Third Sector Foundation of Turkey (TUSEV) Publications. No.51. Ankara-Turkey

Knapp, M., Koutsogeorgopoulou, V.\& Smith, J. (1996). Volunteer participation in community care. Policy and Politics, 24(2): 171-192.

Lum, T.Y. \& Lightfoot, E. (2005). The Effects of Voluntee ring on the Physical and Mental Health of Older People, Research on Aging , 27 (1); 31-55.

OECD. (2011). Help Wanted?: Providing and Paying for Long-Term Care. OECD Press. France. http://www.oecd.org/els/healthpolicie sandda ta/47903344.pdf (accessed 20/9/13).

Ozalp, A. (2008). Sivil toplum Örgütlerinin Toplumsalve Siyasal Bakımdan Önemi. T.C. İçişleri Bakanlığı, De rnekler Dairesi Başkanlığı. Dernekler Denetçiligi Yeterlilik Tezi. Ankara.

http://www.icisle ri.gov.tr/ortak icerik/www. icisle ri/tez9.pdf (a ccessed 20/9/13).

ÖzelSektör Gönüllüler Derneği [OSGD] (2006). Türkiye'de ve ÖzelSektörde Gönüllülük Araştırma sı. Türkiye ÖzelSektör Gönüllüler Derneği. http://www.tusev.org.tr/ (accessed 27/7/13)

Aile ve Sosyal Politikalar Bakanlığı (ASPB), 2011.

Özürlü ve YaşlıHizmetle ri Genel

Müdürlüğüne Bağlı huzurevleri. http://www.ozurluveyasli.gov.tr/tr/

Palaz, S. \& Boz, I. (2008). Üniversite Mezunu Ye tiş kinle rin Farklı Organiza syonlarda Gönüllü Hizmet Vermesini Etkileyen Faktörler. Balıkesir Üniversitesi Sosyal Bilimler Enstitüsü Dergisi, 11 (19): 95-106.

Pennix, K. (2006). The Value of Silver Project, How to mobilise people with experience of life. MOVISIE Ne the rlands Institute of Care and Welfa re (NIZW). www.movisie.nl (accessed 17/1/13).

Pires, C., Prouteau, L. \& Sardinha, B. (2010). Rates of Participation in Volunteering and Cha racteristics of Volunteers: European Comparisons. $9^{\text {th }}$ International Conference of the International Society for Third-Sector Research. Istanbul-Turkey.July 7-10, 2010.

Putnam, R.D. (2000). Bowling alone: The collapse and revival of American community. New York, NY: Simon \& Schuster.

Stanley, M, Moyle, W., Ballantyne, A., Jaworski, K., Corlis, M., Oxla de, D., Stoll, A. \& Young, B. (2010). Nowa days you don't even see your neighbours: Loneliness in the everyday lives of older Australians, Health and Social Care in the Community, 18(4), 407-414.
Tang, F., Morrow-Howell, N. \& Hong, S. (2009). Inclusion of Diverse Older Popula tions in Volunte ering The Importance of Institutional Facilitation. Nonprofit and Voluntary Sector Quarterly. 38, 5; 810-827.

Theiss-Morse, E. \& Hibbing, J. (2005) Citizenship and civic engagement. Annual Review of Political Science, 8: 227-49.

Tilvis, R.S., Laitala, V., Routsalo, P.E. \& Pitkälä, K.H. (2011). Suffering from loneliness indicates significant morta lity risk of older people, Journal of Aging Research, 22; 2011:534781.

TUIK (2010). Demografik Istatistikler,

http://www.tuik.gov.tr (accessed 17/9/13).

Türkiye Eğitim Gönüllüleri Vakfı [TEGV] (2008). Türk Gençlerinde Gönüllülük ve Sosyal Sermaye Sonuç Raporu. Türkiye Eğitim Gönüllüleri Vakf1. www.tegv.org (accessed 17/9/13).

TÜSEV (2006). Türkiye'de Sivil Toplum: Bir Değişim Süreci. Ulusla ra rası Sivil Toplum Endeksi Projesi Türkiye Ülke Raporu, (Edits): Filiz Bikmen, Zeynep, Yayınları No 39.İstanbul.

Wilson D, Justice C, Thomas R, Sheps S, MacAdam M. \& Brown M. (2005). End-of-life care volunteers: a systematic re vie w of the lite rature. Health Services Management Research, 18(4): 244-257.

Yeğen M, Keyman FE, Çalışkan MA, Tol UU. (2010). Türkiye'de Gönüllü Kuruluşlarda Sivil Toplum Kültürü. Yaşama Dair Vakıf (YADA). www.yasamadair.org.tr

Yildirim, N. \& Yildirim, E. (2011). VALUE: Turkey Na tional Report. University Lifelong Learning and Volunteering Across Europe (VALUE): Reflections from the National Reports, http://www.valuenetwork.org.uk/html/turke y.htm (accessed 17/9/13).

İçişleri Bakanlı̆g: http://derbis.dernekler.gov.tr/SSL/istatistik/ille re gor e.aspx 